\title{
Responsabilidade penal ambiental da pessoa jurídica*
}

\section{Environmental criminal liability of legal entity}

André de Paula Viana'

Leonice Domingos

dos Santos Cintra Lima²
Artigo recebido em abril de 2013. Artigo aprovado em abril de 2013.

1 Graduado em Ciências Jurídicas e Sociais, especialista, mestrando, professor universitário.

2 Professora Doutora do Programa de Mestrado em Ciências Ambientais-UNICASTELO-Fernandópolis.

\section{Resumo}

Pela busca da adequação da norma legal em face da evolução social, tem-se que as pessoas jurídicas, de direito público e de direito privado, assim por serem sujeitos de direitos e obrigações, aplicam-se a elas os conceitos que envolvem o tema, o princípio do poluidor pagador e nos termos da legislação vigente e atinente ao tema; aplicam-se ainda os princípios constitucionais relativos ao direito ambiental, os princípios gerais do direito e o princípio da intervenção mínima do direito penal sobre os casos concretos. Assim, neste artigo, serão demonstrados os meios de responsabilização da pessoa jurídica quanto aos crimes ambientais praticados. Via de hermenêutica interpretativa de caso em concreto a ser julgado,, paulatinamente serão fixados conceitos mais exatos a serem utilizados para a pacificação do tema necessária à fixação da essência do crime ambiental pela extensão do dano ambiental causado e pela correlação às pessoas jurídicas. A prima facie, via do tema a ser exposto, a grande problemática é se, de fato, a pessoa jurídica pode ou não sofrer sanção penal pela prática dos crimes ambientais, e mais, se as sanções quais possam ser aplicadas de fato cumprem o objetivo punitivo/pedagógico e reparativo do dano ambiental causado.

Palavras-chave: Meio ambiente. Crimes. Extensão. Reparação. Dano.

\section{Abstract}

By searching the adequacy of the legal norm against social evolution, it has the legal entities of public law and private law, as well as being subject to rights and obligations apply to them the concepts of the subject, the principle the polluter pays principle and in accordance with applicable law and regards the issue; still apply constitutional principles relating to environmental law, general principles of law and the principle of minimum intervention of the criminal law on the individual cases, so the media will be demonstrated accountability of corporate environmental crimes as charged. Via the hermeneutic interpretive particular case to be tried; gradually be fixed concepts more accurate to be used in the pacification of the subject. Needed fixing the essence of environmental crime by the extent of environmental damage and the correlation corporations. The prima facie, via the theme to be exposed, the big issue is whether in fact the person or legal entity may not suffer criminal penalty for practicing environmental crimes and more if the sanctions which can be applied in fact meet the goal punitive / pedagogical and reparative environmental damage caused.

Keywords: Environment. Crime. Extension. Repair damage. 


\section{Introdução}

Em um contexto de dinâmica mutação, considerações intimamente ligadas à responsabilidade ambiental das pessoas jurídicas são constantes. Visto que a busca pelo equilíbrio entre o justo e o injusto; a equidade pacífica e difusa formam a agenda do Direito.

No curso da evolução sociolegal, o próprio conceito de "pessoa", sofre alteração em face da ocorrência e da criação da figura da pessoa jurídica pela pessoa física. Para que a primeira possa existir, adquirir direitos e personalidade jurídica, carece de atuação da segunda.

Por adquirir direitos, possuir personalidade jurídica e patrimônio próprio, mesmo assim ser subjetiva e abstrata, a pessoa jurídica pode causar danos ambientais que até então eram inerentes às pessoas físicas.

Outrora existente com exclusividade às pessoas físicas, contemporaneamente o foco se volta para as pessoas jurídicas e para a necessidade de reparação dos danos ambientais de suas atividades derivados.

O meio ambiente ecologicamente equilibrado é um dos direitos fundamentais da pessoa humana, bem como assegurado às futuras gerações, por isso justificase a imposição de sanções penais à agressão cometida. A tutela ambiental é utilizada somente para intervir nos casos em que a agressão aos valores fundamentais alcance o ponto intolerável ou que seja objeto de imensa reprovação do corpo social.

A preservação e o restabelecimento do meio ambiente é questão de importância e relevância contemporânea. É uma realidade a extinção de espécimes animais e vegetais, fenômenos biológicos, climáticos os quais se exteriorizam por manifestações físicas sobre o planeta.

Conforme normatização constitucional, o artigo $225, \$ 3^{\circ}$ nos traz que: “[...] as condutas e atividades consideradas lesivas ao meio ambiente, sujeitarão os infratores pessoas físicas ou jurídicas, a sanções penais e administrativas, independentes da obrigação de reparar os danos causados".

Aquele que pratica ilícito ambiental, por um mesmo ato pode ser responsabilizado, alternativa ou cumulativamente, na esfera penal, administrativa e civil.
$\mathrm{Na}$ esfera civil, a obrigação reparatória de danos eivados das condutas antiambientais já era expressa antes mesmo da edição e vigência da Constituição Federal de 1988, segundo o princípio da responsabilidade objetiva (independentemente de culpa), disciplinada, desde 1981, pela Lei da Política Nacional do Meio Ambiente. Restando apenas tratar da responsabilidade penal e administrativa, esses foram incorporados ao ordenamento jurídico pela Lei 9.605/98, que dispõe sobre sanções penais e administrativas derivadas de condutas lesivas ao meio ambiente.

\section{Fontes principiológicas do direito ambiental}

\subsection{Princípios da prevenção ou da precaução}

Trata-se de um dos principios mais importantes que norteiam o direito ambiental. Vale observar que, desde a Conferência de Estocolmo, em 1972, o princípio da preservação tem sido objetivo de apreço, lançado à categoria de megaprincípio do direito ambiental, bem delineado no princípio de $\mathrm{n}^{\circ} 15$ da Declaração do Rio (ECO/92).

Pelo mesmo prisma legal, o artigo 225 da Constituição Federal de 1988 estabelece que cabe ao Poder Público e à coletividade o dever de preservar e de proteger o meio ambiente para as futuras e presentes gerações, criando assim uma consciência ecológica, que deve ser desenvolvida por meio de uma política de educação ambiental cujo objetivo principal deve ser a adoção de medidas que impeçam o acontecimento de dano causado ao meio, impedindo que ele seja lesado.

A efetiva prevenção do dano deve ser papel executado pelo Estado, punindo o poluidor e gerando nele um desconforto ou até um medo para que venha realizar nova conduta poluidora, impondo multas e sanções pesadas como instrumento de prevenção, para que o homem aprenda diante de seus erros.

As finalidades da sanção penal abrangem o caráter retributivo do mal cometido, preventivo para que outros não cometam a mesma conduta, visto que serão sabedores de que, para cada ação, existe uma reação e, no caso em comento, para a prática ilícita, reserva-se ao Estado a aplicação da sanção, visto que uma pena resulta em meio de ressocialização do agente infrator. 


\subsection{Princípio do poluidor pagador}

No mesmo prospecto anteriormente mencionado, a Lei da Politica Nacional do Meio Ambiente, de 1981, acolheu o princípio do "poluidor pagador",que pode ser identificado de duas formas de alcance, sendo que a primeira busca evitar a ocorrência de danos ambientais (caráter preventivo) e a segunda, quando ocorrido o dano, visa à reparação, ou seja, retornar ao status quo ante (caráter repressivo e reparativo).

Nessa vertente legislativa, o artigo $14, \$ 1^{\circ}$ completa que "[...] é o poluidor obrigado, independentemente de existência de culpa, a indenizar ou reparar os danos causados ao meio ambiente e a terceiros, afetados por sua atividade [...]."

\subsection{Princípio da responsabilidade}

Existe a interligação e até mesmo a ingerência entre o Principio do Poluidor Pagador e o Principio da Responsabilidade, haja vista que, quando o poluidor se dispõe a arcar com os custos de sua atividade que lesou o meio ambiente, surge então a responsabilidade ambiental.

Vendo que o meio ambiente é direito fundamental, difuso e indispensável à proteção da vida com qualidade, qualquer ato que agrida esse bem, quem o tenha praticado deverá ser reprimido pelo sistema jurídico.

\subsection{Principio do desenvolvimento sustentável}

No tocante ao desenvolvimento sustentável, tem-se que as atividades econômicas deverão respeitar algumas diretrizes pelo objetivo regular da preservação do meio ambiente, ou seja, a ordem econômica, a qual se funda na valorização do trabalho do homem e na livre iniciativa e tem por finalidade assegurar a todos a existência digna, conforme os ditames da justiça social. Agrega-se ao supracitado a necessidade da defesa do meio ambiente, até mesmo pelo tratamento diferenciado conforme impacto ambiental dos produtos e serviços e de seus processos de elaboração e prestação.

Culmina tal realidade capitalista na ideia principal de assegurar a existência digna da pessoa e dos meios de produção; com isso, esse princípio não visa acabar com a atividade econômica, mas minimizá-la, mesmo sabendo que a atividade econômica, por muitas vezes, representa degradação ambiental. O correto seria encontrar o ponto de equilíbrio entre o desenvolvimento e a vertente econômico, sem que isso venha prejudicar o meio ambiente.

\subsection{Princípio da intervenção mínima do direito penal}

O Direito Penal trilha por caminhos novos, ou seja, adentra em uma nova era, pois será abordado como ultima ratio em matéria de responsabilização jurídica.

No caso em comento, vê-se que essa área do Direito pode intervir quando as demais instâncias de responsabilização administrativa e civil, já foram utilizadas e demonstradas como insuficientes para reprimir a conduta que lesou o meio ambiente que é o bem tutelado em questão.

Desse modo, a aplicação penal é medida de excessão, aplicada em última oportunidade por restringir a liberdade da pessoa que é direito fundamental do homem e valor supremo para a vida em sociedade, repercutindo negativamente em seu senso de dignidade, ou seja, quando encontra medida que envolva restrição a esse direito subjetivo, existem certos limites na exata medida do necessário e suficiente para atender o fim público da situação, sendo utilizado somente quando a conduta ofender ou colocar em perigo de ofensa um bem jurídico, não sendo também qualquer bem, tem que ter uma relevância social extrema.

Em específico, temos que, no âmbito do Direito Ambiental, as leis penais são usadas inteiramente para prevenir danos, após suas ocorrências concretas, à sua reparação tempestiva e integral.

Ao caso em comento, nota-se que o ente coletivo entrou no polo ativo do âmbito criminal porque as empresas vêm gerando ataques contra o meio ambiente, com grande destaque às indústrias, sendo que a pessoa jurídica sempre visa lucro, pouco importando com a degradação do meio ambiente, que traz prejuízos tanto em curto quanto em longo prazo, à coletividade, não se importando com a saúde da população, por vezes reproduzindo os ideiais arcaicos da própria revolução industrial.

A proteção do meio coletivo é ato fundamental do poder constituinte, buscando maior proteção com meios coativos mais eficazes e rápidos para combater a destruição do meio ambiente, adequando-se perfeitamente ao princípio da intervenção mínima do Direito Penal. 


\section{Conceito de meio ambiente}

Diversos são os conceitos atribuídos ao meio ambiente, ressaltando que o primeiro a utilizar esse termo e conceituar o conjunto a compor os ecosistemas foi o francês Geoffroy de Saint Hilaire (milieu ambiant) na obra Études progressives d'un naturaliste, de 1835.

Não há um acordo entre os especialistas quanto ao que exatamente seja meio ambiente, tratando-se de uma noção ambígua que exprime ou não as paixões, as expectativas e incorporações daquelas que dele cuidam. É preciso que a expressão seja analisada e explicada minuciosamente em suas diferentes acepções.

Literalmente analisando, temos que o termo "meio" pode significar: aritmética; a medate de um inteiro; um dado contexto físico e social; um recurso ou insumo para alcançar ou para alcançar e produzir algo. Já o termo “ambiente" pode representar um espaço geográfico ou social, físico ou ecológico, natural ou artificial, possuindo apenas o desejo de dar ênfase.

Tem-se então que a palavra "ambiente" indica lugar ou a área onde habitam os seres vivos e coisas. Por uma conclusão técnica então, "meio ambiente" é “[...] a combinação de todas as coisas e fatores externos ao individuo ou à população em questão". Nesse diapasão, meio ambiente então pode ser enxergado sob uma ótica mais ampla e mais estrita.

Na visão ampla, vai além dos limites fixados pela Ecologia tradicional, englobando toda a natureza original (natural), artificial, assim como os bens culturais correlatos. O meio ambiente natural é constituido pelo solo, pela água, pelo ar, pela energia, pela fauna e pela flora; e o artificial ou humano é constituido pelas edificações, equipamentos e alterações produzidas pelo homem, assim como os assentamentos de natureza urbana e demais construções, existindo-se assim um desenvolvimento equilibrado de vida.

Quanto ao conceito jurídico de meio ambiente, para que possamos traçar um paralelo entre a conduta e o resultado danoso ambiental, assim existe a visualização do nexo de causalidade a qual culmina com a responsabilização penal de entes em crimes praticados contra o meio ambiente.

\subsection{Conceito de meio ambiente na Constituição Federal de 1988}

As constituições que precederam a de 1988 não abordavam o tema de proteção ao meio ambiente de for- ma específica e global; inexistia qualquer advertência e até preocupação com o meio ambiente até então.. Já a Constituição Federal de 1988 é uma constituição "verde", visando à proteção total ao meio ambiente.

O cidadão tem ação direta para a preservação e conservação, gerando assim a consciência para a preservaçao e para a reparaçao do meio ambiente, aprendendo a conviver harmonicamente com a natureza. Assim, Constituição Federal de 1988 traz em vários dispositivos a conscientização da essencialidade desse bem jurídico ambiental. Vejamos:

Art. 225. Todos têm direito ao meio ambiente ecologicamente equilibrado, bem de uso comum do povo e essencial à sadia qualidade de vida, impondo-se ao Poder Público e à coletividade o dever de defendê-lo e preservá- lo para as presentes e futuras gerações.

$\$ 1^{\circ}$ - Para assegurar a efetividade desse direito, incumbe ao Poder Público:

I - preservar e restaurar os processos ecológicos essenciais e prover o manejo ecológico das espécies e ecossistemas;

II - preservar a diversidade e a integridade do patrimônio genético do País e fiscalizar as entidades dedicadas à pesquisa e manipulação de material genético;

III - definir, em todas as unidades da Federação, espaços territoriais e seus componentes a serem especialmente protegidos, sendo a alteração e a supressão permitidas somente através de lei, vedada qualquer utilização que comprometa a integridade dos atributos que justifiquem sua proteção;

IV - exigir, na forma da lei, para instalação de obra ou atividade potencialmente causadora de significativa degradação do meio ambiente, estudo prévio de impacto ambiental, a que se dará publicidade;

V - controlar a produção, a comercialização e o emprego de técnicas, métodos e substâncias que comportem risco para a vida, a qualidade de vida e o meio ambiente;

VI - promover a educação ambiental em todos os níveis de ensino e a conscientização pública para a preservação do meio ambiente;

VII - proteger a fauna e a flora, vedadas, na forma da lei, as práticas que coloquem em risco sua função ecológica, provoquem a extinção de espécies ou submetam os animais à crueldade.

$\$ 2^{\circ}$ - Aquele que explorar recursos minerais fica obrigado a recuperar o meio ambiente degradado, de acordo com solução técnica exigida pelo órgão público competente, na forma da lei.

$\$ 3^{\circ}$ - As condutas e atividades consideradas lesivas ao meio ambiente sujeitarão os infratores, 
pessoas físicas ou jurídicas, a sanções penais e administrativas, independentemente da obrigação de reparar os danos causados.

$\$ 4^{\circ}$ - A Floresta Amazônica brasileira, a Mata Atlântica, a Serra do Mar, o Pantanal MatoGrossense e a Zona Costeira são patrimônio nacional, e sua utilização far-se-á, na forma da lei, dentro de condições que assegurem a preservação do meio ambiente, inclusive quanto ao uso dos recursos naturais.

$\$ 5^{\circ}$ - São indisponíveis as terras devolutas ou arrecadadas pelos Estados, por ações discriminatórias, necessárias à proteção dos ecossistemas naturais.

$\$ 6^{\circ}$ - As usinas que operem com reator nuclear deverão ter sua localização definida em lei federal, sem o que não poderão ser instaladas."

\subsection{Conceito legislativo de meio ambiente e fixação dos crimes ambientais}

Os crimes ambientais estão previstos na Lei $\mathrm{n}^{\circ}$ 9.605 de 13.02.98, Lei de Crimes Ambientais (dispõe sobre as Sanções Penais e Administrativas Derivadas de Condutas e Atividades Lesivas ao Meio Ambiente e dá outras providências). A Lei de Crimes Ambientais (LCA) foi estruturada a partir de uma consolidação das infrações já previstas pelo Código de Caça, Código Florestal e o Código de Pesca, mas criou também novas figuras penais. Com a nova Lei, as penas foram uniformizadas, ganharam graduação adequada e as infrações passaram a ser claramente definidas.

Quem, de qualquer forma, concorre para a prática dos crimes previstos na Lei de Crimes Ambientais, incide nas penas a eles cominadas, na medida da sua culpabilidade, bem como o diretor, o administrador, o membro de conselho e de órgão técnico, o auditor, o gerente, o preposto ou mandatário de pessoa jurídica, que, sabendo da conduta criminosa de outrem, deixar de impedir a sua prática, quando podia agir para evitá-la (LCA, art. $2^{\circ}$ ).

\section{Concurso de Pessoas em Crimes Ambientais}

\subsection{Responsabilidade penal da pessoa jurídica}

A Lei de Crimes Ambientais inovou ao estabelecer a responsabilidade criminal das pessoas jurídicas que cometerem infrações de ordem ambiental. As pessoas jurídicas serão responsabilizadas administrativa, civil e penalmente, nos casos em que a infração seja cometida por decisão de seu representante legal ou contratual, ou de seu órgão colegiado, no interesse ou benefício da sua entidade (LCA, art. $3^{\circ}$ ).

A responsabilidade das pessoas jurídicas não exclui a das pessoas físicas, autoras, coautoras ou partícipes do mesmo fato (Lei 9.605/98, art. $3^{\circ}$, parágrafo único).

Importante característica da Lei de Crimes Ambientais é a responsabilização da pessoa jurídica que cometer infração ambiental. No aspecto doutrinário, o estabelecimento da responsabilidade dessas entidades vai contrariamente à Teoria da Ficção, de Savigny, segundo a qual, as pessoas jurídicas não podem ser responsabilizadas, pois são uma abstração, carecendo de vontade própria, consciência e finalidade, imprescindíveis para o fato típico, e também de imputabilidade e de capacidade para ser culpável. Para Savigny, só o homem poderia ser sujeito de direitos e assim os delitos praticados pela pessoa jurídica são de responsabilidade de seus dirigentes.

Entretanto, outra corrente aponta que esse entendimento não deve ser absoluto para todos os crimes. Há crimes que só podem ser praticados por pessoas físicas, como o homicídio e o estupro, mas há outros que, por suas características, são cometidos quase exclusivamente por pessoas jurídicas e, sobretudo, no exclusivo interesse delas. Na grande maioria das vezes, os casos graves de poluição ou outros desastres que afetam o meio ambiente são causados por grandes grupos empresariais e até mesmo órgãos estatais. Assim, em contraposição à Teoria da Ficção, surgiu a Teoria da Realidade, baseando-se em pressupostos totalmente diversos. A pessoa moral passa a ser vista não somente como um ser artificial, criado pelo Estado, mas sim um ente real (vivo e ativo), independente dos indivíduos que a compõem. Do mesmo modo que uma pessoa física atua como o indivíduo, ainda que mediante procedimentos diferentes e pode, por conseguinte, cometer crimes e ser punida. Para essa teoria, pessoa não é somente o homem, mas todos os entes possuidores de existência real, abrangendo aí tanto a pessoa física como a jurídica.

Assim, com base na necessidade de se proteger de modo amplo o ambiente e manter esse patrimônio para as futuras gerações, o legislador permitiu a responsabilidade penal da pessoa jurídica no ordenamento pátrio, ignorando a resistência doutrinária penal - que entende que estaria se ofendendo o princípio da pessoalidade, o princípio da individualização e o princípio da proporcionalidade da 
pena. Atualmente, diversos países já adotam a responsabilidade penal da pessoa jurídica, como, Inglaterra, Estados Unidos, Holanda, Dinamarca, Portugal e França.

Vale lembrar que, antes da edição da Lei de Crimes Ambientais, a responsabilidade penal da pessoa jurídica já havia sido prevista expressamente no art. $225, \S 3^{\circ}$ da Constituição Federal, que dispõe: “[...] $\$ 3^{\circ}$ - As condutas e atividades consideradas lesivas ao meio ambiente sujeitarão os infratores, pessoas físicas ou jurídicas, a sanções penais e administrativas, independentemente da obrigação de reparar os danos causados”.

\subsection{A conduta e a vontade da pessoa jurídica}

Para as pessoas jurídicas, tem-se que analisar os pontos relativos à capacidade de ação e à vontade do ente coletivo, aplica-se a teoria do delito, na qual trabalha o conceito analítico do crime como fato típico, antijurídico e culpável, ás pessoas jurídicas.

Existem posiciomentos contrários à responsabilização da pessoa jurídica, baseando-se em dois argumentos para mostrar que somente o ser humano é capaz de ser responsável pelos seus atos, pois tem consciência e vontade para realizar certa atividade com seu fim desejado.

A ação praticada pela pessoa jurídica, a denominada pela doutrina de ação institucional, possui diferença da realização por pessoa física, em virtude de existir relação entre a instituição e seus integrantes.

Além da chamada ação e responsabilidade institucional, cita-se que a pessoa jurídica tem responsabilidade em outras áreas como a civil e a administrativa, sendo sujeito da relação e vindo a participar, ou seja, responsável pela sua atuação tanto lícita quanto ilícita em sociedade, impedindo assim, tratamento diferenciado.

\section{Apuração da Responsabilidade penal da pessoa jurídica}

O meio ambiente é protegido de forma independente na esfera administrativa, civil e penal. Na esfera civil, a reparação independe de culpa do infrator (responsabilidade objetiva), porém na esfera administrativa e penal, faz-se necessária a demonstração do dolo ou culpa.

Para responsabilizar penalmente a pessoa jurídica, é necessário que a infração tenha sido cometida: a) por decisão de seu representante legal (presidente, diretor, administrador, gerente, etc.);

b) por decisão contratual (preposto ou mandatário de pessoa jurídica, auditor independente, etc.); e

c) por decisão de órgão colegiado (órgão técnico, conselho de administração, acionistas reunidos em assembleia etc.).

\subsection{Desconsideração da pessoa jurídica}

Poderá ser desconsiderada a pessoa jurídica sempre que sua personalidade for obstáculo ao ressarcimento de prejuízos causados à qualidade do meio ambiente (LCA, art. $4^{\circ}$ ).

\subsection{Responsabilidade penal da pessoa jurídica de direito público}

O Estado tem o papel de ser responsável pelas mudanças do progresso social, o qual se delimita pelo ordenamento jurídico vigente, trilhando rumos pela incontestável aceitação e pela aplicabilidade da responsabilização penal da pessoa jurídica de direito privado; quanto ao ente de direito publico, resta lídimo que ele também deverá responder civilmente pelo ato da recomposição civil dos danos causados.

Outra tese forte para responsabilização das pessoas jurídicas de direito publico é que a penalização desses entes serviria com freio e imputaria maior cuidado por parte dos deles e de seus administradores (prefeitos, governadores, presidente etc.) para com o meio ambiente.

\section{A aplicação da pena}

\subsection{Aplicação da pena}

Conforme o art. $6^{\circ}$, para imposição e gradação da penalidade, a autoridade competente observará:

\footnotetext{
I - a gravidade do fato, tendo em vista os motivos da infração e suas consequências para a saúde pública e para o meio ambiente;

II - os antecedentes do infrator quanto ao cumprimento da legislação de interesse ambiental;

III - a situação econômica do infrator, no caso de multa.
}

$\mathrm{O}$ art. $6^{\circ}$ da Lei 9.605/98 criou mais algumas circunstâncias judiciais, as quais entram na primeira fase, jun- 
tamente com as constantes do art. 59 do Código Penal. Trata-se de circunstâncias específicas, as quais somente têm incidência no caso de crimes previstos na Lei Ambiental.

\subsection{Circunstâncias}

\subsubsection{Atenuantes}

São circunstâncias que atenuam a pena:

- baixo grau de instrução ou escolaridade do agente;

- arrependimento do infrator, manifestado pela espontânea reparação do dano, ou limitação significativa da degradação ambiental causada;

- comunicação prévia pelo agente do perigo iminente de degradação ambiental;

- colaboração com os agentes encarregados da vigilância e do controle ambiental.

\subsubsection{Circunstâncias agravantes}

São circunstâncias que agravam a pena, quando não constituem ou qualificam o crime:

- reincidência nos crimes de natureza ambiental;

- $\quad$ ter o agente cometido à infração:

a) para obter vantagem pecuniária;

b) coagindo outrem para a execução material da infração;

c) afetando ou expondo a perigo, de maneira grave, a saúde pública ou o meio ambiente;

d) concorrendo para danos à propriedade alheia;

e) atingindo áreas de unidades de conservação ou áreas sujeitas, por ato do Poder Público, a regime especial de uso;

f) atingindo áreas urbanas ou quaisquer assentamentos humanos;

g) em período de defeso à fauna;

h) em domingos ou feriados;

i) à noite; j) em épocas de seca ou inundações;

k) no interior do espaço territorial especialmente protegido;

1) com o emprego de métodos cruéis para abate ou captura de animais;

m) mediante fraude ou abuso de confiança;

n) mediante abuso do direito de licença, permissão ou autorização ambiental;

o) no interesse de pessoa jurídica mantida, total ou parcialmente, por verbas públicas ou beneficiada por incentivos fiscais;

p) atingindo espécies ameaçadas, listadas em relatórios oficiais das autoridades competentes;

q) facilitada por funcionário público no exercício de suas funções.

\section{Quantificação para a Reparação do Dano Causado}

A sentença penal condenatória, sempre que possível, fixará o valor mínimo para reparação dos danos causados pela infração, considerando os prejuízos sofridos pelo ofendido ou pelo meio ambiente. Transitada em julgado a sentença condenatória, a execução poderá efetuar- se pelo valor fixado nos termos do "caput", sem prejuízo da liquidação para apuração do dano efetivamente sofrido (LCA, art. 20).

\section{Aplicação da pena às pessoas jurídicas}

A Lei Ambiental estabelece três modalidades de pena a serem aplicadas à pessoa jurídica:

- multa, restritivas de direitos ou prestação de serviços à comunidade, que podem ser aplicadas isolada, cumulativa ou alternativamente (LCA, art. 21).

\subsection{Penas restritivas de direitos}

As penas restritivas de direitos da pessoa jurídica são: 
- suspensão parcial ou total de atividades que deverá ser aplicada quando estas não estiverem obedecendo às disposições legais ou regulamentares, relativas à proteção do meio ambiente;

- interdição temporária de estabelecimento, obra ou atividade; será aplicada quando estabelecimento, obra ou atividade estiver funcionando sem a devida autorização, ou em desacordo com a concedida, ou com violação de disposição legal ou regulamentar;

- proibição de contratar com o Poder Público, bem como dele obter subsídios, subvenções ou doações (esta pena não poderá exceder o prazo de dez anos).

\subsection{Prestação de serviços à comunidade}

A prestação de serviços à comunidade pela pessoa jurídica consistirá em:

- custeio de programas e de projetos ambientais;

- execução de obras de recuperação de áreas degradadas;

- manutenção de espaços públicos;

- contribuições a entidades ambientais ou culturais públicas.

\subsection{Liquidação forçada de empresas}

A pessoa jurídica constituída ou utilizada, preponderantemente, com o fim de permitir, facilitar ou ocultar a prática de crime definido nesta Lei terá decretada sua liquidação forçada, seu patrimônio será considerado instrumento do crime e como tal perdido em favor do Fundo Penitenciário Nacional. (LCA, art. 24)

\subsection{Jurisprudências de crime ambiental}

EMENTA: APELAÇÃO CRIME. DELITO AMBIENTAL. PROPOSTA DE SUSPENSÃO CONDICIONAL DO PROCESSO. ACEITA A PROPOSTA PELO ACUSADO E SEU DEFENSOR, O JUIZ PODERÁ ESPECIFICAR OUTRAS CONDIÇÕES A QUE FICA SUBORDINADA A SUSPENSÃO, DESDE QUE ADEQUADAS AO FATO E A SITUAÇÃO PESSOAL DO ACUSADO, NOS TERMOS DO PARÁGRAFO 2 DO ART. 89 DA LEI 9.099/95. A LEI FACULTA AO MAGISTRADO INTER-
VIR NA FIXAÇÃO DAS CONDIÇÕES DA SUSPENSÃO DO PROCESSO, ALTERANDO A PROPOSTA INICIAL DO MINISTÉRIO PÚBLICO. NEGARAM PROVIMENTO. UNÂNIME.

RECURSO: APELAÇÃO CRIME NÚMERO: 70001813971 TRIBUNAL: TRIBUNAL DE JUSTIÇA DO RS DATA DE JULGAMENTO: 28/12/2000 RELATOR: ARISTIDES PEDROSO DE ALBUQUERQUE

EMENTA: CRIME AMBIENTAL. PROVA EMPRESTADA. SUBSTITUIÇÃO DE PENA. A ATIVIDADE CONSISTENTE EM DEPOSITAR O LIXO DOMESTICO E INDUSTRIAL DA CIDADE EM LOCAL INADEQUADO E PROIBIDO, SEGUNDO COMPROVAÇÃO TÉCNICA, CARACTERIZA A PRATICA DE CRIME AMBIENTAL. PROVA PERICIAL PRODUZIDA NO JUÍZO CÍVEL PODE SER APROVEITADA NO PROCESSO CRIMINAL QUE DISCUTE O MESMO FATO, OBSERVADO O CONTRADITÓRIO. APRESENTANDO-SE FAVORÁVEIS AS CIRCUNSTANCIAS JUDICIAIS E INOCORRENTES AGRAVANTES, A PENA PRIVATIVA DE LIBERDADE INFERIOR A QUATRO ANOS DECORRENTE DA CONDENAÇÃO PELA PRATICA DE CRIME AMBIENTAL, PODE SER SUBSTITUÍDA POR ATRIBUIÇÃO DE TAREFA GRATUITA JUNTO A PARQUES E JARDINS PÚBLICOS E UNIDADES DE CONSERVAÇÃO, PELO PRAZO DA SANÇÃO SUBSTITUÍDA. VOTO VENCIDO. (PCR No 695062950, QUARTA CÂMARA CRIMINAL, TRÊS, RELATOR: DES. VLADIMIR GIACOMUZZI, JULGADO EM 30/04/1998).

TRIBUNAL: TRIBUNAL DE JUSTIÇA DO RS DATA DE JULGAMENTO: 30/04/1998 ÓRGÃO JULGADOR: QUARTA CÂMARA CRIMINAL COMARCA DE ORIGEM: ROLANTE SEÇÃO: CRIME

RECURSO: PROCESSO CRIME NÚMERO: 695062950 RELATOR VENCIDO: WALTER JOBIM NETO REDATOR PARA ACÓRDÃO: VLADIMIR GIACOMUZZI

FONTE: JURISPRUDÊNCIA TJRS, C-CRIM, 1998, V-1, T-11, P-46-64 EMENTA: PREFEITO MUNICIPAL. CRIME CONTRA O MEIO AMBIENTE. DENUNCIA. RECEBIMENTO. A PREOCUPAÇÃO DO PREFEITO MUNICIPAL COM A DEGRADAÇÃO DO MEIO AMBIENTE, LIMITANDO-SE A PEDIR A INDICAÇÃO DE UM TÉCNICO AO ÓRGÃO ESTADUAL ENCARREGADO DA FISCALIZAÇÃO E CONCESSÃO DE LICENÇA, NÃO E O BASTANTE PARA AFASTAR A IMPUTAÇÃO PELO CRIME DE POLUIÇÃO DO MEIO AMBIENTE, EXPONDO A PERIGO A VIDA HUMANA, ANIMAL OU VEGETAL, SE SUA CONDUTA DESRESPEITA AS REGRAS MÍNIMAS, QUE ERAM DO SEU CONHECIMENTO, NA ESCOLHA 
DE ÁREA PARA DEPOSITO DO LIXO URBANO. AS PROVIDENCIAS POSTERIORES AO PERÍODO IMPUTADO E DECORRENTES DE AÇÃO CIVIL PÚBLICA TAMBÉM NÃO ELIDEM A IMPUTAÇÃO. DENUNCIA RECEBIDA. (PCR No 696803683, QUARTA CÂMARA CRIMINAL, TJRS, RELATOR: DES. DANÚBIO EDON FRANCO, JULGADO EM 18/09/1997).

TRIBUNAL: TRIBUNAL DE JUSTIÇA DO RS DATA DE JULGAMENTO: 18/09/1997 ÓRGÃO JULGADOR: QUARTA CÂMARA CRIMINAL COMARCA DE ORIGEM: DOM PEDRITO SEÇÃO: CRIME

RECURSO: PROCESSO CRIME NÚMERO: 696803683 RELATOR: DANÚBIO EDON FRANCO

FONTE: JURISPRUDÊNCIA TJRS, C-CRIM, 1997, V-2,T-5, P-133-137. PROV. EMENTA: PREFEITO MUNICIPAL. CRIME ECOLÓGICO. PARA O RECEBIMENTO DA DENUNCIA, BASTA QUE SE DEMONSTRE MATERIALIDADE DO DEPOSITO DA SUBSTANCIA TOXICA EM LOCAL INADEQUADO. (PCR No 694122680, QUARTA CRIME, TJRS, RELATOR: DES. VLADIMIR GIACOMUZZI, JULGADO EM 17/08/1995).

TRIBUNAL: TRIBUNAL DE JUSTIÇA DO RS DATA DE JULGAMENTO: 17/08/1995 ÓRGÃO JULGADOR: QUARTO CRIME COMARCA DE ORIGEM: DOIS IRMÃOS SEÇÃO: RECURSO: PROCESSO CRIME NUMERO: 694122680 RELATOR: VLADIMIR GIACOMUZZI FONTE: JURISPRUDÊNCIA TJRS, C-CRIM, 1995, V-1, T-5, P-145-152. EEE

DIREITO PENAL. PROCESSO PENAL. CRIME AMBIENTAL. CRIME CONTRA A FLORA. AÇÃO PENAL JULGADA PROCEDENTE. PENA DETENTIVA APLICADA. SUBSTITUIÇÃO DA PENA PRIVATIVA DE LIBERDADE POR PRESTAÇÃO PECUNIÁRIA" (Processo n. ${ }^{\circ}$ 70001949361, da 4a Câmara Crime, Rel. Des. Vladimir Giacomuzzi, j. em 13/12/2003).

PENAL - PROCESSO PENAL - CRIME AMBIENTAL - DIREITO INTERPORAL - LEI N. ${ }^{\circ}$ 6.938/81 - ART. 15 E LEI N. ${ }^{\circ} 9.605 / 98$ - ART. 54 - PRESCRIÇÃO PELA PENA CONCRETIZADA. Sentença condenatória mantida com correta classificação jurídico-penal da lei aplicável ao fato. Proclamação da prescrição, diante do montante da pena privativa de liberdade aplicada”. (Processo n. ${ }^{0}$ 70006570568, 4a Câmara Criminal, Rel. Des. Vladimir Giacomuzzi, j. em 28/08/2003).

DIREITO PENAL. PROCESSO PENAL. CRIME AMBIENTAL. Ação penal julgada procedente, em parte, para absolver dois dos acusados e para condenar o terceiro pela prática do crime do art. 54, V da Leu n. ${ }^{\circ}$ 9.605/98, praticado em caráter permanente a partir de janeiro de 2001 até abril de 2002. Pena de reclusão fixada em dois anos em razão de anteriores condenações e do caráter permanente do delito praticado. Sem "sursis" ou substituição por encontrar-se o réu em situação de cumprimento de pena aplicada noutro processo" (Processo n. ${ }^{\circ} 70004302907,4^{a}$ Câmara Criminal, Rel. Des. Vladimir Giacomuzzi, j. em 06/11/2003)

DIREITO PENAL - CRIME AMBIENTAL AÇÃO PENAL JULGADA PROCEDENTE." (Processo n. ${ }^{\circ}$ 70001364124, $4^{\circ}$ Câmara Criminal, Rel. Des. Vladimir Giacomuzzi, j. em 18/12/2004).

APELAÇÃO-CRIME. DENÚNCIA. REJEIÇÃO. CRIME AMBIENTAL. RESPONSABILIDADE PENAL DA PESSOA JURÍDICA. A Constituição Federal de 1988, em seu art. 225, $\$ 3^{\circ}$, determina expressamente que a pessoa jurídica está sujeita às sanções penais quando praticar condutas e atividades lesivas ao meio ambiente. Da mesma forma, preceitua o art. $3^{\circ}$ da Lei no 9605/98. Assim, não aceitar a responsabilização penal da pessoa jurídica é negar cumprimento à Carta Magna e à lei. Recurso de apelação julgado procedente. (Apelação Crime No 70009597717, Quarta Câmara Criminal, Tribunal de Justiça do RS, Relator: José Eugênio Tedesco, Julgado em 14/10/2004).

HABEAS CORPUS. CRIME AMBIENTAL. SUSPENSÃO CONDICIONAL DO PROCESSO. APLICABILIDADE DOS INCISOS II, III E IV DO ARTIGO 89 DA LEI 9.099/95. INTELIGÊNCIA DO ARTIGO 28, INCISO III, DA LEI 9.605/98. ARGUIÇÃO DE NULIDADE DO PACTO ACORDADO. INEXISTÊNCIA. CONDIÇÃO VIOLADORA DA DIGNIDADE HUMANA

PROCEDÊNCIA. EXPOSIÇÃO DESNECESSÁRIA. DIGNIDADE DA PESSOA HUMANA (CF, ARTIGO $1^{\circ}$, III). ORDEM PARCIALMENTE CONCEDIDA

HC n. ${ }^{\circ}$ 39.576-BA, Rel. Min. Hélio Quaglia Barbosa, julgado em 24/2/2005.

\section{Conclusão}

Pela evolução da norma legal, caminhando de encontro à necessidade social de proteção do meio ambiente, tem-se que indubitavelmente as pessoas jurídicas, sejam estas de direito privado ou público, respondem de forma objetiva pelos danos ambientais causados, nas esferas civis, administrativas e penais.

Quanto à responsabilização penal, esta ocorre dada a ficção da personalização da pessoa jurídica, sendo essa pessoa de direitos e obrigações, ou seja, por vezes 
convertendo a privação da liberdade dada sua impossibilidade física, visto que é um ser abstrato, porém podendo-se converter esta em penas pecuniárias, prestação de serviço à comunidade ou até mesmo, pelo principio da correlação e atração, pela desconsideração da pessoa jurídica, aplica-se as penas privativas de liberdade a seus proprietários, representantes legais ou administradores públicos, nos casos de abuso do poder econômico e até mesmo quando do desvio de finalidade institucionalmente atribuídas quando da constituição da pessoa jurídica.

A legislação vigente e atinente ao caso em tela, no tocante a responsabilização penal das pessoas jurídicas evoluiu sensivelmente, sendo rechaçada pela doutrina e jurisprudência, impondo as pessoas jurídicas degradadoras do meio ambiente, exemplares punições, cumprindo assim seu caráter punitivo/pedagógico.

\section{Referências}

DOTTI, René Ariel. Incapacidade Criminal da Pessoa Jurídica: uma perspectiva do direito brasileiro. In: PRADO, Luiz Régis (coord). Responsabilidade penal da pessoa jurídica: em defesa do princípio da imputação penal subjetiva. São Paulo: Revista dos Tribunais, 2001.

FREITAS, Vladimir Passos de; FREITAS, Gilberto Passos de. Crimes contra a natureza: de acordo com a lei 9.605/98. 6. ed. São Paulo: Revista dos Tribunais, 2000.

LECEY, Eladio. Responsabilidade Penal da Pessoa Jurídica: Efetividade e Questões Processuais. In: CONGRESSO INTERNACIONAL DE DIREITO AMBIENTAL FAUNA, POLÍTICAS PÚBLICAS E INSTRUMENTOS LEGAIS, 8., 2004, São Paulo. Anais... São Paulo: Instituto "O Direito por um Planeta Verde", 2004.

LECEY, Eladio. A Atividade Empresarial e a Corresponsabilidade Penal da Pessoa Jurídica e do Dirigente na Lei dos Crimes Contra o Ambiente. In: CURSO DE DIREITO AMBIENTAL PENAL, 4. , 2004. Porto Alegre. Rio Grande do Sul: Instituto "O Direito por um Planeta Verde", 2004.

MARCHESAN, Ana Maria Moreira. Alguns aspectos sobre a lei dos crimes ambientais. Revista de Direito Ambiental, São Paulo, n. 19, p. 67-81, jul./set. 2000.

SANCTIS, Fausto Martins de. Responsabilidade penal da pessoa jurídica. São Paulo: Saraiva, 1999.

SIRVINSKAS, Luís Paulo. Tutela penal do meio ambiente: breves considerações atinentes à Lei n. 9.605, de 12-21998. 3.ed. São Paulo: Saraiva, 2004.

SOUSA, Gaspar Alexandre de. Crimes ambientais: responsabilidade penal das pessoas jurídicas. Goiânia: AB, 2003. 